\title{
Cystic fibrosis transmembrane conductance regulator gene abnormalities in patients with asthma and recurrent neutrophilic bronchitis
}

\author{
Jodi Goodwin MD FRCPC, Naomi Spitale MD FRCPC, Asma Yaghi PhD, \\ Myrna Dolovich P Eng, Parameswaran Nair MD PhD FRCP FRCPC
}

\begin{abstract}
J Goodwin, N Siptale, A Yaghi, M Dolovich, P Nair. Cystic fibrosis transmembrane conductance regulator gene abnormalities in patients with asthma and recurrent neutrophilic bronchitis. Can Respir J 2012;19(1):46-48.

The present case series describes four patients with asthma, airway hyperresponsiveness and neutrophilic bronchitis who harboured abnormal cystic fibrosis transmembrance conductance regulator (CFTR) gene mutations. It serves both to alert clinicians to consider CFTR-related disease in both young and elderly patients with persistent neutrophilic bronchitis, and to highlight the potential utility of future genetic testing for CFTR abnormalities in patients with asthma and recurrent bronchitis or pansinusitis, and the role of nebulized hypertonic saline as a therapeutic option in these patients.
\end{abstract}

Key Words: Asthma; CFTR gene mutations; Neutrophilic bronchitis; Sputum

Pystic fibrosis (CF) is an autosomal recessive disorder resulting from mutations in the CF transmembrane regulator (CFTR) gene $(1,2)$. The CFTR gene is responsible for coding a 1480 amino acid protein that functions as a cyclic adenosine monophosphateregulated chloride channel (an ATP-binding cassette transporter). This channel regulates water and ion transport across membranes, and is found in the epithelium of secretory epithelial cells in the lungs, liver, pancreas, intestine, reproductive tracts and sweat glands. Mutations in the gene are associated with decreased mucociliary clearance, leading to pathogenic bacterial colonization and an inflammatory cascade. Within the respiratory tract, this results in irreversible bronchiectasis and, ultimately, respiratory failure (3). Currently, 1604 mutations are listed in the CF database, 39 of which are tested for in routine CFTR analysis, which encompasses $90 \%$ of mutations found in the Caucasian population (4).

Because the link between chloride channel dysregulation and clinical disease is not clearly defined, non-CF gene modifiers and environmental factors are believed to play a role (5). Several studies have hypothesized that some nondisease-causing CFTR mutations are associated with a spectrum of hyperinflammatory pulmonary manifestations (6). The present case series highlights an association between various CFTR mutations, asthma and recurrent neutrophilic bronchitis. This clinical association promotes the hypothesis that such mutations, although not causally linked with CF, are associated with pathophysiological changes such as altered rheology of pulmonary secretions, upregulation of the innate immune system and abnormal CFTR protein on airway smooth muscle cells. These various clinical pulmonary manifestations can potentially be considered to be at one end of a continuum with those found in classic CF.

\section{CASE PRESENTATIONS}

Four patients (one male, three female, all older than 60 years of age) who were referred to the Firestone Institute of Respiratory Health (Hamilton, Ontario) for evaluation of their asthma, productive cough and recurrent bronchitis are reported. They experienced an average of

\author{
Des anomalies du gène régulateur de la perméabilité \\ transmembranaire de la fibrose kystique chez des \\ patients atteints d'asthme et de bronchite à \\ neutrophiles récurrente
}

La présente série de cas décrit quatre patients atteints d'asthme, d'hypersensibilité des voies aériennes et de bronchite à neutrophiles qui présentaient des mutations anormales du gène régulateur de la perméabilité transmembranaire de la fibrose kystique (CFTR). Elle permet à la fois de signaler aux cliniciens d'envisager une maladie liée au gène CFTR chez les patients ayant une bronchite à neutrophiles persistante et à souligner l'utilité potentielle de futurs tests génétiques des anomalies du gène CFTR chez les patients ayant de l'asthme et une bronchite récurrente ou une pansinusite ainsi que le rôle des solutés physiologiques hypertoniques en aérosol comme solution thérapeutique chez ces patients.

four infective exacerbations of their asthma each year for the preceding three years. One patient (case 4) had a daughter who harboured a nondefining mutation of the CFTR gene. CF had not previously been considered in their diagnostic workup by their referring respirologists. They underwent the following investigations: pre and postbronchodilator spirometry, methacholine bronchial provocation test (when indicated), quantitative sputum cell counts (7), sputum culture, sweat chloride assay (8), quantitative immunoglobulin assay, chest and sinus computed tomography scans and genotyping for CFTR mutations (9). Three patients also had ciliary beat frequency of nasal epithelial cells assessed using high-speed digital video microscopy (Redlake MASD Inc, USA) and ProAnalyst software (XCitex, USA) (10).

The clinical features and results of investigations are summarized in Tables 1 and 2. All patients were treated with the appropriate antibiotics. Inhaled corticosteroid dosage was reduced to the optimum dose to keep the eosinophil percentage lower than 1\% (median dose fluticasone equivalent $1000 \mu \mathrm{g}$ daily). All patients were also commenced on 5\% saline nebulization using a low-output nebulizer and were recommended $2 \mathrm{~mL}$ to $5 \mathrm{~mL}$ twice daily premedicated by salbutamol. Over the following two years of follow-up, one patient experienced two exacerbations of symptoms that were associated with a trivial neutrophilia (negative bacteriology), one patient had two exacerbations, each of which was associated with sputum eosinophilia $(6.5 \%)$, and the other two have remained free of exacerbations.

\section{DISCUSSION}

We described the clinical histories of four patients with asthma and recurrent or persistent neutrophilic bronchitis, in whom the importance of checking for CFTR gene mutations and the clinical benefit of hypertonic saline aerosol is highlighted.

In our patients, other non-CF causes of neutrophilic bronchitis such as occupational exposures, immune deficiency disorders, ciliary dyskinesia, chronic aspiration, inflammatory bowel disease and atypical mycobacterial or chlamydial infection were ruled out with history, physical examination and appropriate investigations.

Firestone Institute for Respiratory Health, St Joseph's Healthcare and Department of Medicine, McMaster University, Hamilton, Ontario Correspondence: Dr Parameswaran Nair, Firestone Institute for Respiratory Health, St Joseph's Healthcare, 50 Charlton Avenue East,

Hamilton, Ontario L8N 4A6. Telephone 905-522-1155 ext 35044, fax 905-521-6183, e-mail parames@mcmaster.ca 
TABLE 1

Spirometry and sputum cell counts

\begin{tabular}{|c|c|c|c|c|c|c|c|c|c|}
\hline \multirow[b]{2}{*}{ Patient, age, years } & \multirow[b]{2}{*}{$\mathrm{FEV}_{1}, \mathrm{~L}$} & \multirow[b]{2}{*}{$\mathrm{FEV}_{1} \%$} & \multirow[b]{2}{*}{$\begin{array}{c}\mathrm{FEV}_{1} / \mathrm{VC} \\
\%\end{array}$} & \multirow[b]{2}{*}{$\begin{array}{c}\Delta \mathrm{FEV}_{1}, \% \\
\text { post-bd }\end{array}$} & \multirow[b]{2}{*}{$\begin{array}{l}\mathrm{PC}_{20} \\
\mathrm{mg} / \mathrm{mL}\end{array}$} & \multicolumn{3}{|c|}{ Sputum cell count } & \multirow[b]{2}{*}{ Sputum culture } \\
\hline & & & & & & $\begin{array}{c}\text { TCC* }^{*} \\
\text { (normal }<9.7 \text { ) }\end{array}$ & $\begin{array}{c}\text { Eosinophils, \% } \\
\text { (normal <2.0) }\end{array}$ & $\begin{array}{c}\text { Neutrophils, \% } \\
\text { (normal <64) }\end{array}$ & \\
\hline Female, 80 & 0.8 & 43 & 65 & 18 & Not tested & 40 & 0 & 98 & $\begin{array}{l}\text { Pseudomonas aeruginosa, } \\
\text { Haemophilus influenzae, } \\
\text { Aspergillus fumigatus }\end{array}$ \\
\hline Female, 60 & 2.31 & 83 & 75 & 12 & 6 & 10.5 & 0 & 95.5 & $\begin{array}{l}\text { Staphylococcus aureus, } \\
\text { Aspergillus fumigatus }\end{array}$ \\
\hline Female, 66 & 1.99 & 79 & 69 & 15 & 7.2 & 18.4 & 0 & 77 & Haemophilus influenzae \\
\hline
\end{tabular}

${ }^{*} T C C$ Total cell count $\left(\times 10^{6}\right.$ cells/g); bd Bronchodilator; FEV ${ }_{1}$ Forced expiratory volume in $1 \mathrm{~s} ; P_{20}$ Provocative concentration of methacholine causing a $20 \%$ fall in FEV ${ }_{1}$; VC Vital capacity

TABLE 2

Clinical charactersitics and cystic fibrosis transmembrane conductance regulator (CFTR) mutations

\begin{tabular}{|c|c|c|c|c|c|c|}
\hline Case & $\begin{array}{l}\text { Sweat chloride, } \\
\mathrm{mmol} / \mathrm{L}\end{array}$ & Sinus disease & Bronchiectasis & Ciliary beat frequency & Immunoglobulins & CFTR mutation \\
\hline 1 & 30 & Absent & Present & Not tested & Normal & $\begin{array}{l}\text { Hetero for } 1 \text { disease causing Gly551Asp; } \\
\text { Hetero for } 4 \text { polymorphisms: Thr854Thr, } \\
\text { GIn1463GIn, 1001+11C } \rightarrow \text { T and } \\
\text { 6-GATT/7-GATT; Homo for one } \\
\text { polymorphism: Val470Met }\end{array}$ \\
\hline 2 & 24 & Present & None & Normal & $\begin{array}{l}\text { Immunoglobulin E } \\
7000 \text { (ABPA) }\end{array}$ & $\begin{array}{l}\text { Hetero for } 1 \text { disease causing Phe508del; } \\
\text { Hetero for } 3 \text { polymorphisms: } 125 \mathrm{G} \rightarrow \mathrm{C} \text {, } \\
\text { Thr854Thr, } 1001+11 \mathrm{C} \rightarrow \mathrm{T} \text {; Homo for two } \\
\text { polymorphisms: Met470Val and 6-GATT; } \\
\text { Intron 8T tract status: } 7 \mathrm{~T} / 9 \mathrm{~T}\end{array}$ \\
\hline 3 & 31 & Present & Present & Normal & Normal & $\begin{array}{l}\text { Hetero for one polymorphism: Val470Met; } \\
\text { Homo for two polymorphisms: 7-GATT/7- } \\
\text { GATT; Intron 8T tract status: } 5 T / 7 T\end{array}$ \\
\hline 4 & 29 & Present & Present & Normal & Normal & $\begin{array}{l}\text { Hetero for one disease causing Arg117His; } \\
\text { Intron } 8 \mathrm{~T} \text { tract status: } 5 \mathrm{~T} / 7 \mathrm{~T}\end{array}$ \\
\hline
\end{tabular}

ABPA Allergic bronchopulmonary aspergillosis; del Deletion; Hetero Heterozygous; Homo Homozygous

Previous studies have investigated potential associations between mutations in the CFTR gene and bronchial hyper-responsiveness with conflicting results. The Epidemiological Study of the Genetics and Environment of Asthma, Bronchial Hyperresponsiveness, and Atopy reported that the $\Delta \mathrm{F} 508$ mutation was not associated to a significant extent with asthma (3.2\% of carriers versus $2.9 \%$ of controls) (11). Others have suggested that the $\Delta \mathrm{F} 508$ mutation can be protective for heterozygotes in the context of bronchial asthma (12). In contrast, three studies have reported an association between $\Delta \mathrm{F} 508$ mutation and pansinusitis $(6)$, asthma $(13,14)$ and airflow limitation (15). Finally, a previous case series (16) found an association between mutations in CFTR that alter RNA splicing and/or functional chloride conductance to susceptibility and pathogenesis of adult bronchiectasis and pulmonary nontuberculous mycobacteria infection. This illustrates the importance of careful phenotying in genetic linkage and genome-wide association studies. Our case histories suggest that the association may be stronger in patients with asthma and a neutrophilic bronchitis.

The pathophysiology of lung damage in CF, including decreased mucociliary clearance, bacterial infection and retention, and inflammatory response leading to bronchiectasis, has been well described (17). One commonality between this pathway and the clinical phenotypes described in our case series is the underlying upregulation of the innate immune system, particularly neutrophils. A link between mutations in the CFTR protein and neutrophilia, mediated by smooth muscle cells and interleukin-8 has been established (18). Furthermore, decreased mucociliary clearance, which precedes infection, inflammation and innate immune response (hallmarked by neutrophilia) has previously been speculated to be present not only in CF patients, but also in a continuum of causes of chronic wet cough such as persistent bronchitis, chronic lung disease and bronchiectasis $(19,20)$.
Hypertonic saline administration has previously been demonstrated to be efficacious in CF patients with regard to improvements in levels of lung function, frequency of exacerbations and antibiotic use during exacerbations (21). The theory behind the mechanism of action stems from the isotonic volume depletion hypothesis, which stipulates that CF mutations result in excess salt reabsorption across the respiratory epithelium, dehydrating airway mucous secretions and resulting in decreased mucociliary clearance, and increased rates of infection. Although hyperosmolar agents are useful in CF-related and non CF-related bronchiectasis (22), hypertonic saline has not specifically been evaluated in non-CF bronchiectasis. The clinical course of our patients suggests that hypertonic saline may also be beneficial to those with hyperinflammatory states linked to a broader spectrum of CFTR mutations. This warrants a prospective randomized clinical trial of nebulized hypertonic saline in patients with asthma and persistent or recurrent neutrophilic bronchitis, and various CFTR mutations with or without bronchiectasis. In contrast to a recent report (23), we did not identify any abnormalities in ciliary motility in our patients with severe asthma.

ACKNOWLEDGEMENT: Dr Nair is funded by a Canada Research Chair in Airway Inflammometry.

\section{SUMMARY}

The present case series serves both to alert clinicians to consider a potential diagnosis of CFTR-related disease in patients with persistent neutrophilic bronchitis or sinusitis and asthma, and to highlight the potential utility of future genetic testing for CFTR abnormalities. As well, a potential role for nebulized hypertonic saline as a therapeutic option, in such individuals warrants consideration based on the clinical improvement seen in our case series. 


\section{REFERENCES}

1. Rommens JM, Iannuzzi MC, Kerem B, et al. Identification of the cystic fibrosis gene: Chromosome walking and jumping. Science 1989;245:1059-65.

2. Collins FS. Cystic fibrosis: Molecular biology and therapeutic implications. Science 1992;256:774-9.

3. Gibson RL, Burns JL, Ramsey BW. Pathophysiology and management of pulmonary infections in cystic fibrosis. Am J Respir Crit Care Med 2003;168:918.

4. Cystic Fibrosis Mutation Database < www.genet.sickkids.on.ca> (Accessed on September 9, 2010).

5. Mehta A, Bush A. Beyond chloride transport: CFTR in the 21st century. Pediatr Pulmonol 2005;39:289-91.

6. Noone PG, Knowles, MR. 'CFTR-opathies': Disease phenotypes associated with cystic fibrosis transmembrane regulator gene mutations. Respir Res 2001;2:328-32.

7. Nair P, Hargreave FE. Measuring bronchitis in airway diseases: Clinical implementation and application. Chest 2010;138:38S-43S.

8. Ip W, Turner D, Han WS, Rose J, Durie P, Quinton P. Sweat gland bioelectrics differ in cystic fibrosis: A new concept for potential diagnosis and assessment of CFTR function in cystic fibrosis. Thorax 2009;64:932-8.

9. Farrell PM, Rosenstein BJ, White TB, et al. Guidelines for diagnosis of cystic fibrosis in newborns through older adults: Cystic Fibrosis Foundation consensus report. Guidelines for diagnosis of cystic fibrosis in newborns through older adults. J Pediatr 2008;153:S4-S14.

10. Dolovich MB, Mahony JB, Chambers C, Newhouse MT, Chernesky MA. Ciliary function, cell viability, and in vitro effect of ribavirin on nasal epithelial cells in acute rhinorrhea. Chest 1992;102:284-7.

11. De Cid, R, Chomel JC, Lazaro C et al. CFTR and asthma in the French EGEA study. Eur J Hum Genet 2001:9;67-9.

12. Schroeder SA, Gaughan DM, Swift M. Protection against bronchial asthma by CFTR delta F508 mutation: A heterozygote advantage in cystic fibrosis. Nat Med 1995;1:703-5.
13. Dahl M, Tybjaerg-Hansen, A, Lange, P, Nordestgaard, BG. Delta F508 heterozygosity in cystic fibrosis and susceptibility to asthma. Lancet 1998;351:1911-3.

14. Lowenfels AB, Maisonneuve P, Palys B, Schoni MH, Redemann B. Delta F508 heterozygosity and asthma. Lancet 1998;352:985.

15. Douros K, Loukou I, Doudounakis S, Tzetis M, Priftis KN, Kanavakis E. Asthma and pulmonary function abnormalities in heterozygotes for cystic fibrosis transmembrane regulator gene mutations. Int J Clin Exp Med 2008:1;345-9.

16. Ziedalski TM, Kao PN, Henig NR, Jacobs SS, Ruoss SJ. Prospective analysis of cystic fibrosis and transmembrance regulator mutations in adults with bronchiectasis or pulmonary nontuberculous mycobacterial infection. Chest 2006;130:1995-1002.

17. Davis PB. Pathophysiology of the lung disease in cystic fibrosis. New York: Marcel Dekker, 1993:193.

18. Michoud MC, Robert R, Hassan M, et al. Role of the cystic fibrosis transmembrane conductance channel in human airway smooth muscle. Am J Respir Cell Mol Bio 2008;40:217-22.

19. Chang AB, Redding GJ, Everard ML. Chronic wet cough: Protracted bronchitis, chronic suppurative lung disease and bronchiectasis. Pediatr Pulmonol 2008;43:519-31.

20. Marchant JM, Gibson PG, Grissell TV, Timmins NL, Masters IB, Chang A. Prospective assessment of protracted bacterial bronchitis: Airway inflammation and innate immune activation. Pediatr Pulmonol 2008;43:1092-9.

21. Elkins MR, Robinson M, Rose BR, et al. A controlled trial of long-term inhaled hypertonic saline in patients with cystic fibrosis. N Engl J Med 2006;354:229-40.

22. Wills P, Greenstone M. Inhaled hyperosmolar agents for bronchiectasis. Cochrane Database Syst Rev 2006;2:CD002996.

23. Thomas B, Rutman A, Hirst RA, et al. Ciliary dysfunction and ultrastructural abnormalities are features of severe asthma. J Allergy Clin Immunol 2010;126:722-9.e2. 


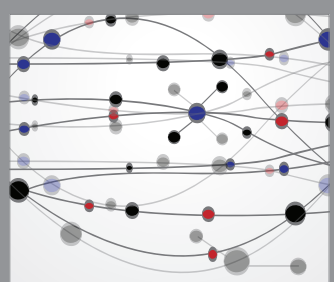

The Scientific World Journal
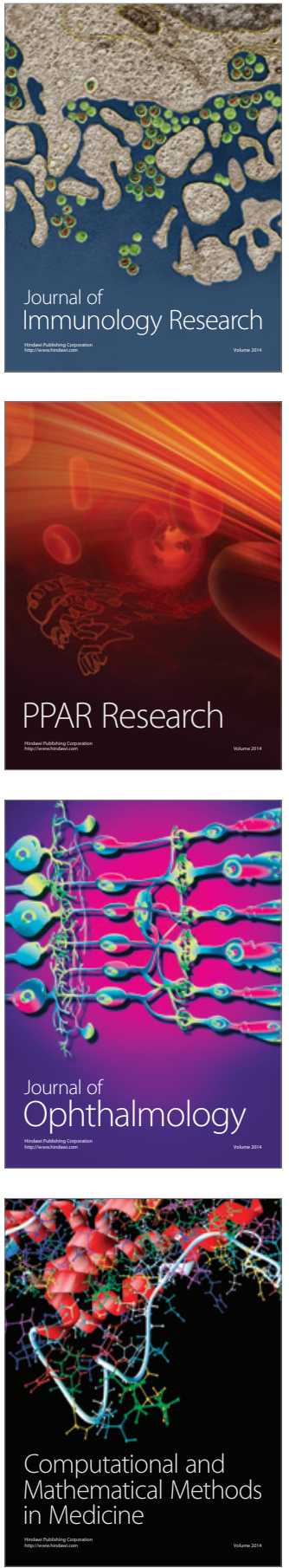

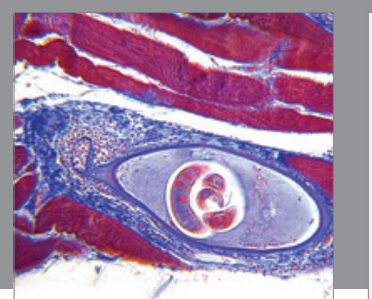

Gastroenterology Research and Practice

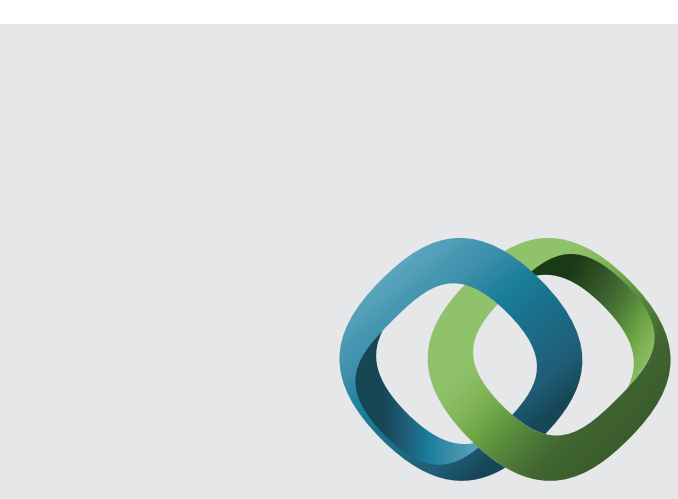

\section{Hindawi}

Submit your manuscripts at

http://www.hindawi.com
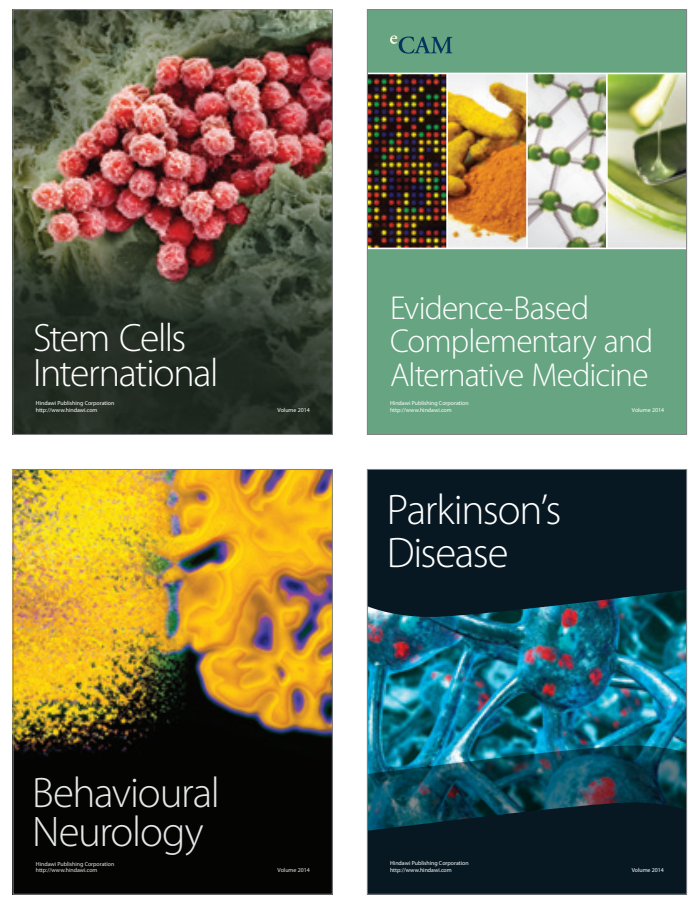
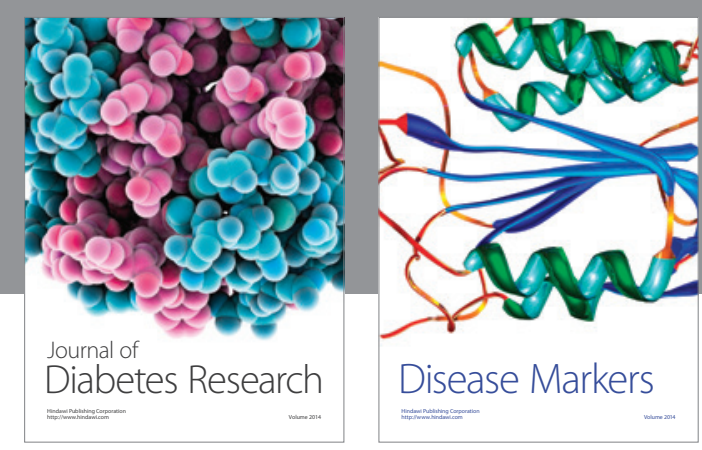

Disease Markers
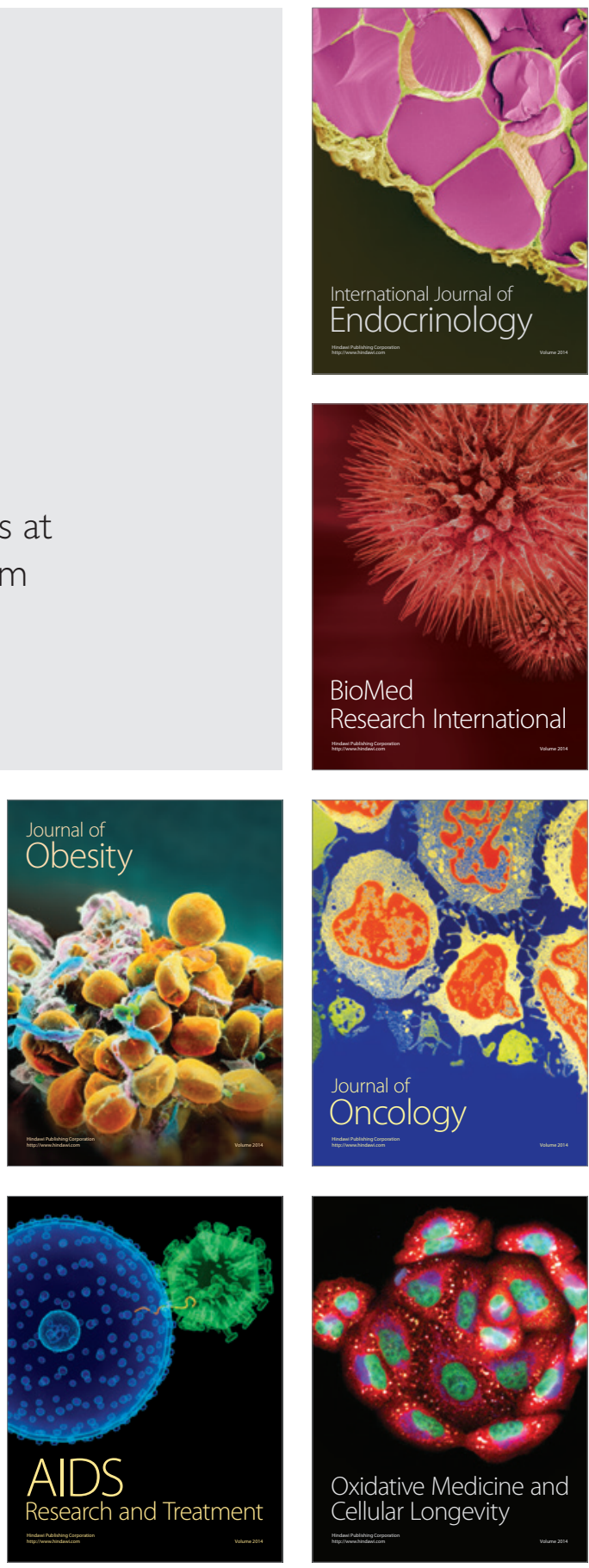